\title{
Acute renal failure with ACE inhibition in aortic coarctation
}

\author{
P.A. Woodmansey, W.W. Yeo, P.R. Jackson and L.E. Ramsay
}

Sheffield Hypertension Clinic, University Department of Medicine and Pharmacology, Royal Hallamshire Hospital, Sheffield S10 2JF, UK

\begin{abstract}
Summary: A 43 year old man with inoperable aortic coarctation and severe hypertension requiring near maximal anti-hypertensive treatment was admitted in severe heart failure. After 2 weeks of treatment the heart failure and blood pressure were incompletely controlled and angiotensin converting enzyme (ACE) inhibitor was started. Serum creatinine was normal before starting the ACE inhibitor and on discharge from hospital. The patient was re-admitted a week later with gross fluid retention and in renal failure. In the absence of alternative causes, a diagnosis of ACE inhibitor-induced renal failure was made and treatment was stopped. The patient required haemodialysis for 2 days and within 1 week the renal function had reverted to normal and has remained so for 1 year. We propose that the renal haemodynamics in severe aortic coarctation are similar to those in bilateral severe renal artery stenosis and advise caution in the use of ACE inhibitors for adults with aortic coarctation.
\end{abstract}

\section{Introduction}

Angiotensin-converting enzyme (ACE) inhibitors now have a prominent role in managing heart failure and hypertension. They are generally well tolerated and safe, but infrequently cause renal failure ${ }^{1}$ typically in patients with bilateral severe renal artery stenosis ${ }^{2}$ or stenosis of the artery serving a single functioning kidney. ${ }^{2,3}$ We report a patient with aortic coarctation who developed reversible acute renal failure after starting ACE inhibitor treatment, and suggest that ACE inhibitors should be used with caution in severe coarctation.

\section{Case report}

A 43 year old male construction worker known to have inoperable aortic coarctation and severe hypertension was admitted in 1991 with uncontrolled left ventricular failure. Hypertension and clinical features of coarctation had been discovered 19 years before, when aged 25 , at a routine examination for employment. Arteriography confirmed a tight 'shelf-like' coarctation at an unusually distal position at the level of T12. Surgical exploration at that time confirmed the tight coarctation at the level of T12 with a length of approx-

Correspondence: Professor L.E. Ramsay, F.R.C.P. Accepted: 25 May 1994 imately $4 \mathrm{~cm}$. An attempt at repair had to be abandoned because of numerous very large thinwalled collateral vessels, and he was managed medically. Blood pressure control proved difficult, with readings often $>200 / 110 \mathrm{mmHg}$ until the introduction of minoxidil and frusemide 11 years before admission. Thereafter blood pressure averaged $164 / 90 \mathrm{mmHg}$ while taking atenolol $50 \mathrm{mg}$, hydralazine $200 \mathrm{mg}$, minoxidil $40 \mathrm{mg}$ and frusemide $160 \mathrm{mg}$ daily. He had severe left ventricular hypertrophy but remained symptom-free until 3 years before admission, when he developed atrial fibrillation and mild cardiac failure. The latter was controlled by increasing the dose of frusemide to $250 \mathrm{mg}$ daily. He was reassessed for possible surgical treatment but the risk was considered prohibitive. Throughout this time renal function remained normal with serum creatinine averaging $95 \mu \mathrm{mol} / \mathrm{l}$.

When admitted he had had 2 weeks of increasing exertional dyspnoea, orthopnoea, paroxysmal nocturnal dyspnoea and oedema. Examination revealed disproportionate muscle development of the upper body, atrial fibrillation at $110 /$ minute, blood pressure of $162 / 98 \mathrm{mmHg}$, peripheral oedema, widespread prominent superficial collaterals, displaced thrusting apex beat, a long loud precordial systolic murmur and femoral pulses, which were readily palpable and slightly delayed. An electrocardiogram (ECG) showed atrial fibrillation and severe left ventricular hypertrophy, a chest X-ray showed cardiomegaly, rib notching and pulmonary 
oedema, and an echocardiogram severe concentric left ventricular hypertropy with normal valves. Serum creatinine was $100 \mu \mathrm{mol} / \mathrm{l}$. He was treated initially by stopping atenolol, adding digoxin and amiloride, and increasing the dose of frusemide to $500 \mathrm{mg}$ daily. After 12 days his heart failure was incompletely controlled and the blood pressure was still high (average 175/105 $\mathrm{mmHg}$ ), and ACE inhibitor treatment was introduced. Amiloride was stopped, frusemide was omitted temporarily and an initial dose of captopril $6.25 \mathrm{mg}$ was given without ill-effect, and particularly without hypotension. Treatment was continued with enalapril and he was discharged 3 days later taking enalapril $5 \mathrm{mg}$ daily with frusemide $500 \mathrm{mg}$, minoxidil and digoxin. Serum creatinine was normal before starting the ACE inhibitor $(70 \mu \mathrm{mol} / \mathrm{l})$ and on discharge 3 days later $(74 \mu \mathrm{mol} / 1)$.

He was re-admitted 6 days after discharge with gross fluid retention. He was virtually anuric for 24 hours and now had serum creatinine of $805 \mu \mathrm{mol} / 1$, urea $48.6 \mathrm{mmol} / \mathrm{l}$, sodium $129 \mathrm{mmol} / \mathrm{l}$, potassium $5.4 \mathrm{mmol} / \mathrm{l}$ and bicarbonate $18 \mathrm{mmol} / \mathrm{l}$. Urine showed trace proteinuria but no blood, cells or casts. Blood pressure was $174 / 70 \mathrm{mmHg}$. In the absence of alternative causes, a presumptive diagnosis of acute renal failure caused by ACE inhibitor treatment was made and enalapril was stopped. He required haemodialysis for 2 days (Figure 1) but had a prompt diuresis, with urine output on successive days 1.6, 5.5 and 6.7 litres. His serum creatinine returned to normal within 1 week (Figure 1). Other than the ACE inhibitor, all drugs taken previously were reintroduced, and renal function has remained normal (Figure 1) even when the dose of frusemide was subsequently increased to $1,000 \mathrm{mg}$ daily.

\section{Discussion}

The acute renal failure was ascribed to ACE inhibitor treatment because of the close temporal relationship, the rapid and complete recovery after enalapril was withdrawn and the absence of any other recognized cause of acute renal failure. At no time did he have hypotension or volume depletion, which might precipitate acute renal failure. ACE inhibitors have rarely precipitated renal failure in patients with pre-existing renoparenchymal disease, ${ }^{4}$ prolonged severe diarrhoea, ${ }^{1}$ or concomitant use of non-steroidal anti-inflammatory drugs, ${ }^{1}$ but none of these circumstances were present. We propose that the renal haemodynamics in this patient with severe aortic coarctation resembled those of bilateral severe renal artery stenosis and that the acute renal failure had a mechanism similar to the renal failure induced by ACE inhibitors in critical renovascular disease. ${ }^{5}$ In health the renal blood flow and glomerular filtration rate remain relatively constant when mean arterial pressure varies over a wide range. This autoregulation is effected by changes in preglomerular resistancec and by the arteriole leading from the glomer ulus-efferent arteriolar resistance. Normally renal blood flow is kept constant largely by changes in

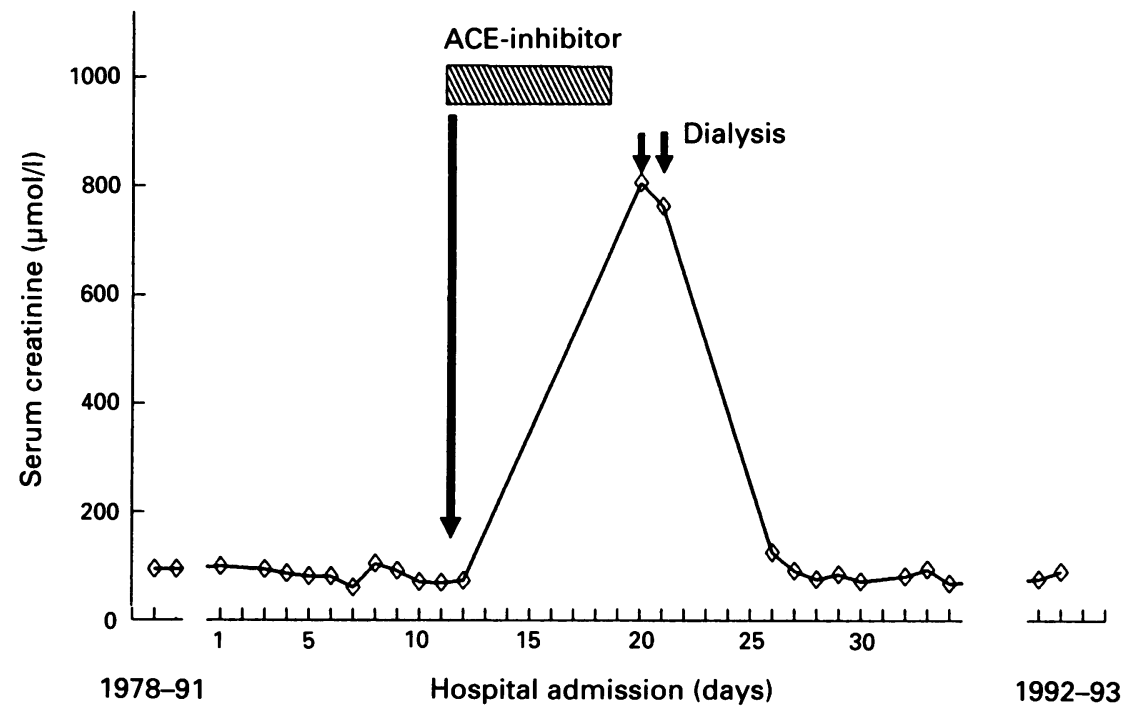

Figure 1 Changes in serum creatinine concentration related to angiotensin converting enzyme (ACE) inhibitor therapy. 
preglomerular resistance rather than at the efferent arteriolar level. However, at the lower end of the autoregulatory range, preglomerular resistance is minimal and glomerular filtration rate then depends on an increase in efferent arteriolar resistance. This increase in postglomerular resistance is mediated by a direct intrarenal effect of angiotensin II, and renal perfusion and glomerular filtration are thus critically dependent upon angiotensin $\mathrm{II} .{ }^{5}$ In this situation ACE inhibition decreases postglomerular resistance with consequent reduction or even cessation of glomerular filtration. ${ }^{5}$ This is the mechanism of the renal failure, which occurs with ACE inhibitor therapy in a significant proportion of patients with bilateral severe renal artery stenosis $^{2}$ or stenosis of the artery to a solitary functioning kidney., ${ }^{2,3}$

In the low pressure system distal to an aortic coarctation, we propose that in some cases renal autoregulation may be in the range where it is

\section{References}

1. Speirs, C.J., Dollery, C.T., Inman, W.H.W., Rawson, N.S.B. \& Wilton, L.V. Postmarketing surveillance of enalapril. II: Investigation of the potential role of enalapril in deaths with renal failure. $\mathrm{Br}$ Med J 1988, 297: 830-832.

2. Hricik, D.E., Browning, P.J., Kopelman, R., Goorno, W.E., Madias, N.E. \& Dzau, V.J. Captopril-induced functional renal insufficiency in patients with bilateral renal-artery stenosis or renal-artery stenosis in a solitary kidney. $N$ Engl $J$ Med 1983, 308: 373-376.

3. Curtis, J.J., Luke, R.G., Whelchel, J.D., Diethelm, A.G., Jones, P. \& Dunstan, H.P. Inhibition of angiotensin converting enzyme in renal-transplant recipients with hypertension. N Engl J Med 1983, 308: 377-381.

4. Traindl, O., Pohanka, E. \& Kovarik, J. Progression of chronic renal failure. Lancet 1988, ii: 962-963.

5. Blythe, W.B. Captopril and renal autoregulation. $N$ Engl J Med 1983, 308: 390-391.

6. Bailie, M.D., Donoso, V.S. \& Gonzalez, N.C. Role of the renin-angiotensin system in hypertension after coarctation of the aorta. J Lab Clin Med 1984, 104: 553-562. dependent on angiotensin II-induced efferent arteriolar constriction. There is evidence from both animal and human studies that the renin angiotensin system is activated in coarctation, ${ }^{6-9}$ presumably as a renal protective mechanism. In this patient the atypical site and the length of the coarctation, starting at T12 and extending for $4 \mathrm{~cm}$, may have resulted in the coarct involving the renal arteries and thus influencing renal haemodynamics directly. Patients with severe and atypical coarctation may therefore be at risk of developing renal failure with ACE inhibitor therapy as occurred in this case. ACE inhibitors have been used with variable success to control blood pressure in patients with coarctation as a temporary measure to prepare infants with cardiac failure for corrective surgery. ${ }^{10-12}$ Renal failure has not been reported but nevertheless we advise caution in the use of ACE inhibitors for adult patients with severe coarctation of the aorta.

7. Fallo, F., Maragno, I., Merola, P. \& Mantero, F. Effect of captopril on blood pressure and on the renin-angiotensin-aldosterone system in coarctation of the aorta. Clin Exp Hypertens 1983, 5: 321-328.

8. Whitlow, P.L. \& Katholi, R.E. Neurohumoral mechanisms in acute aortic coarctation in conscious anaesthetized dogs. Am J Physiol 1983, 244: H614-621.

9. Ribeiro, A.B. \& Krakoff, L.R. Angiotensin blockade in coarctation of the aorta. $N$ Engl J Med 1976, 295: 148-150.

10. Fallo, F., Maragno, I. \& Mantero, F. Resistance to captopril in hypertension of coarctation of the aorta. Int $J$ Cardiol 1985, 9: $111-113$.

11. Frenneaux, M., Stewart, R.A.H., Newman, C.M.H. \& Halladie-Smith, K.A. Enalapril for severe heart failure in infancy. Arch Dis Child 1989, 64: 219-223.

12. Schneeweiss, A. Cardiovascular drugs in children. II. Angiotensin converting enzyme inhibitors in paediatric patients. Pediat Cardiol 1990, II: 199-207. 